\title{
An integrative review of drug utilization by the elderly in primary health care*
}

\author{
Uma revisão integrativa sobre o uso de medicamentos \\ por idosos na atenção primária à saúde \\ Una revisión integradora sobre el uso de fármacos por \\ ancianos en la atención primaria de salud
}

Luciane Paula Batista Araújo de Oliveira', Sílvia Maria Azevedo dos Santos²

How to cite this article:

Oliveira LPBA, Santos SMA. An integrative review of drug utilization by the elderly in primary health care. Rev Esc Enferm USP. 2016;50(1):163-74. DOI: http:// dx.doi.org/10.1590/S0080-623420160000100021

* Extracted from the thesis "A pessoa idosa controlando sua situação de saúde/doença com o uso de medicamentos", Programa de PósGraduação em Enfermagem, Universidade Federal de Santa Catarina, 2015.

${ }^{1}$ Universidade Federal do Rio Grande do Norte, Faculdade de Ciências da Saúde do Trairi, Santa Cruz, RN, Brazil.

${ }^{2}$ Universidade Federal de Santa Catarina, Departamento de Enfermagem, Florianópolis, SC, Brazil.

\begin{abstract}
Objective: To identify knowledge produced about drug utilization by the elderly in the primary health care context from 2006 to 2014. Method: An integrative review of the PubMed, LILACS, BDENF, and SCOPUS databases, including qualitative research papers in Portuguese, English, and Spanish. It excluded papers with insufficient information regarding the methodological description. Results: Search found 633 papers that, after being subjected to the inclusion and exclusion criteria, made up a corpus of 76 publications, mostly in English and produced in the United States, England, and Brazil. Results were pooled in eight thematic categories showing the current trend of drug use in the elderly, notably the use of psychotropics, polypharmacy, the prevention of adverse events, and adoption of technologies to facilitate drug management by the elderly. Studies point out the risks posed to the elderly as a consequence of changes in metabolism and simultaneous use of several drugs. Conclusion: There is strong concern about improving communications between professionals and the elderly in order to promote an exchange of information about therapy, and in this way prevent major health complications in this population.
\end{abstract}

\section{DESCRIPTORS}

Drug Utilization; Aged; Primary Health Care; Geriatric Nursing; Review. 


\section{INTRODUCTION}

The aging process can lead to changes that may affect drug metabolism. This is a concerning fact, mainly regarding how the elderly experience the daily use of medications, and especially if we take into consideration the potential complications in terms of their health.

One should keep in mind that aging is not a homogeneous process. Each patient presents with individual pharmacokinetic variations including absorption, distribution, metabolism, and excretion of drugs ${ }^{(1)}$.

Drug utilization in the elderly is truly epidemic, and this may be associated with different factors such as: increased prevalence of chronic Non-Communicable Diseases (NCD) in this population segment; high health medicalization reported in the last few years and propelled by the pharmaceutical industry's power; and the incentive to prescribe drugs observed in both the training and practice of health professionals, among others ${ }^{(2)}$.

It is worth mentioning that the frequent use of medications in the elderly can be considered as not just an attempt to treat comorbidities but, above all, as a way to mitigate common aging situations ${ }^{(3)}$.

The use of several drugs, combined or not with other supplementary health care forms, is a common practice in the elderly and is frequently described in the literature as a current problem due to complications resulting from adverse reactions and their effects on health system costs. Other studies have identified polypharmacy and the frequency of daily doses of medications as a stressing agent for people, for example, with type 2 diabetes mellitus ${ }^{(4)}$.

In the face of this panorama, and to foster the debate about how drug utilization in the elderly in primary health care plays an important role, we suggest an integrative review based on the following question: In the scientific literature between 2006 and 2014, which would be the state-of-theart regarding drug utilization in the elderly in the context of primary health care?

As this review is part of a grounded theory-based qualitative study, it focuses on scientific productions of a qualitative nature, with the goal of identifying knowledge produced about drug utilization in the elderly in the primary health care context from 2006 to 2014 .

\section{METHOD}

This is a literature review following an integrative ${ }^{(5)} \mathrm{re}^{-}$ view model where productions employed a qualitative approach in studies on aging and drug utilization in primary health care.

Following were the databases consulted: PubMed/Medline (National Library of Medicine and National Institutes of Health); LILACS (Literatura Latino-Americana e do Caribe em Ciências da Saúde); BDENF (Base de Dados de Enfermagem); and SCOPUS.

Following were the descriptors used (all found in the DeCS and MESH): Drug utilization in plural and singular, with "s" and "z"; Medications; Family health Strategies and related terms such as "Family health", "family health
Program"; Primary health care and related terms such as "primary care", "primary health"; Aged and terms such as "Aged 80 and over", "elderly", "older"; and Qualitative Research, "qualitative study", "qualitative studies", "qualitative analysis", "qualitative methods".

To be considered, the articles should meet the following criteria:

- Inclusion criteria: Complete research articles and reviews in Portuguese, English, and Spanish published in scientific journals from 2006 to 2014. This timeframe was selected based on the year of publication of the World Health Organization's document on safe drug utilization in public health services ${ }^{(6)}$. Only articles of a qualitative nature were used-in consideration of the method adopted by the research of which this review is part-and those that provided an overview of what has been studied on drug utilization in the elderly in light of that approach.

- Exclusion criteria: Editorials, reviews, experience reports, and theoretical reflections; dissertations, theses, and monographs; and abstracts published on proceedings. Repeated articles were excluded, and only the first version found was maintained; publications not directly related to the topic were also excluded. Likewise, articles where the methodological description had insufficient information for readers to understand the research process were disregarded. In this way, the documents maintained informed, at least: type of study; approach; population; data collection techniques; and tools.

\section{Search Strategies}

\section{PubMed/Medisne}

("drug utilization" [MeSH Terms] OR "drug utilization" [All Fields] OR "drug utilisation" [All Fields] OR "medication" [All Fields] OR "medications" [All Fields]) AND ("family health" [MeSH Terms] OR "family health" [All Fields] OR "family health Strategies" [All Fields] OR "family health Strategy" [All Fields] OR "family health Program" [All Fields] OR "primary health care" [MeSH Terms] OR "primary health care" [All Fields] OR "primary care" [All Fields] OR "primary health" [All Fields]) AND ("aged" [MeSH Terms] OR "Aged 80 and over" [Mesh] OR "elderly" [All Fields] OR "older" [All Fields]) AND ("qualitative research" [MeSH Terms] OR ("qualitative" [All Fields] AND "research" [All Fields]) OR "qualitative research" [All Fields] OR ("qualitative" [All Fields] AND "study" [All Fields]) OR "qualitative study" [All Fields] OR ("qualitative" [All Fields] AND "studies" [All Fields]) OR "qualitative studies" [All Fields] OR ("qualitative" [All Fields] AND "analysis" [All Fields]) OR "qualitative analysis" [All Fields] OR ("qualitative" [All Fields] AND "methods" [All Fields]) OR "qualitative methods" [All Fields] OR ("qualitative" [All Fields] AND "method" [All Fields]) OR "qualitative method" [All Fields] AND (“2006/01/01" [PDAT]: "2014/12/31" [PDAT]) AND (English[lang] OR Portuguese[lang] OR Spanish[lang]) 


\section{LILACS (VIA BVS)}

("Uso de Medicamentos"OR "Utilización de Medicamentos" OR "Drug Utilization" OR medicamento\$ OR medication\$ OR drug\$) AND (ESF OR (Estratégia AND Saúde AND Família\$) OR (Programa AND Saúde AND Família\$) OR PSF OR "Saúde da Familia" OR "Atenção Primária" OR "Atenção básica" OR "cuidados primários" OR "Estrategia de Salud de la Familia" OR ESF OR "Programa de Salud de la Familia" OR "Salud de la Familia" OR "Atención Primaria" OR "Atención básica" OR "family health" OR "primary care" OR "primary health") AND (Idoso\$ OR envelhecimento OR velhice OR anciano OR Aged OR elderly OR older)

\section{BDEnf (VIA BVS)}

("Uso de Medicamentos"OR "Utilización de Medicamentos" OR "Drug Utilization" OR medicamento\$ OR medication\$ OR drug\$) AND ESF OR (Estratégia AND Saúde AND Família\$) OR (Programa AND Saúde AND Família\$) OR PSF OR "Saúde da Familia" OR "Atenção Primária" OR "Atenção básica" OR "cuidados primários" OR "Estrategia de Salud de la Familia" OR ESF OR "Programa de Salud de la Familia" OR "Salud de la Familia" OR "Atención Primaria" OR "Atención basica" OR "family health" OR "primary care" OR "primary health") AND (Idoso\$ OR envelhecimento OR velhice OR anciano OR Aged OR elderly OR older)

\section{SCOPUS (VIA PERIÓDICOS CAPES)}

("drug utilization" OR "drug utilization" OR "medication" OR "medications") AND ("family health" OR "family health Strategies" OR "family health strategy" OR "family health Program" OR "primary health care" OR "primary care" OR "primary health") AND ("aged" OR "Aged 80 and over" OR "elderly" OR "older") AND ("qualitative research" OR "qualitative study" OR "qualitative studies" OR "qualitative analysis" OR "qualitative methods" OR "qualitative method")

\section{RESULTS}

The search strategies slightly differ due to the peculiarities of each database. LILACS and BDEnf did not allow insertions in the search strategy terms referring to qualitative research or time excerpt and, as such, these criteria were further applied. In this way, of the 315 articles initially identified in the LILACS using the aforementioned strategy, after applying the limits "qualitative research" and its synonyms in addition to the time excerpt, 260 remained to have the abstracts analyzed. The same reduction happened with BDEnf, as the 27 articles identified through the search strategy, after been subjected to limits, were reduced to 24 articles. SCOPUS, in turn, allowed search using the terms "qualitative research, study, and/or method," but the filters of language and time (01/01/2006 to 12/31/2014) had to be applied later. In this database, the use of these filters had no major impact on the number of articles, as these dropped from 182 to 181 articles subject to abstract analysis. PubMed/Medline was the only database consulted that allows the application of all limits by the time of the research strategy.

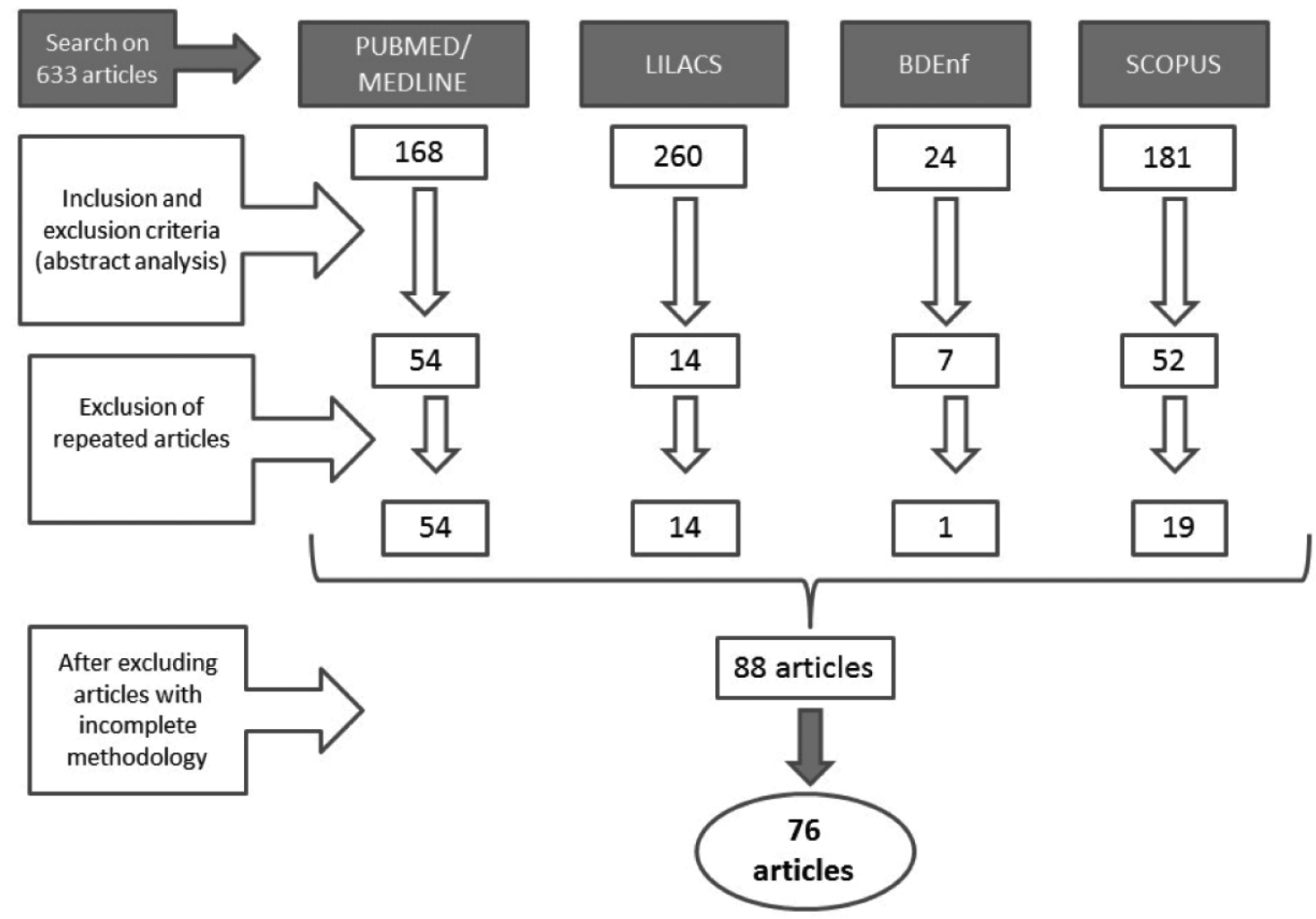

Figure 1 - Number of articles identified in the database according to the descriptors and limits established and the corpus selected for the integrative review - Santa Cruz, RN, Brazil, 2015. 
As the 76 selected articles were read, the main information was organized in a summary table comprising: author/ year identification; article title; objective; methodology used; main results; and researcher remarks and/or relevant extracts highlighted in the article. This way of organizing data enabled better visualization of the information gathered, helping the categorization of articles according to the objective of each article.

Most of the 76 articles selected to be part of the corpus of this review were published in 2011 (16 articles) and decreased in the following years: 2013 with 15; and 2012 with 14 articles. Eight articles were identified for 2010, while for 2006, 2008, 2009, and 2014 five articles were published in each year. The year with the fewest publications on this topic was 2007 with three articles identified.

English was the main language (60 articles), followed by Portuguese (14 articles) and Spanish (two articles). The prevalence of publications in English does not mean that all articles were produced in English-speaking countries; rather, it shows that English is adopted as the language of publication by many countries, including Brazil. Most of the articles identified resulted from studies developed in the USA (27 articles), Brazil (16), England (10), Australia (six), New Zealand (two), Belgium, Germany, Malaysia, Holland (two articles each), Cuba, Denmark, Ireland, Sweden, Spain, Switzerland, and Singapore (one article each).

The analysis of the corpus also regarded the methodological path followed by the articles; however, we faced the following difficulty: many articles did not itemize important methodological aspects, bringing about doubts regarding what the authors did to reach such important results in their studies. In line with our search strategies all articles selected were of a qualitative nature. Some were research extracts with mixed methods; however, those with missing essential aspects regarding methodology were excluded. In this way the 76 articles making up the analyzed corpus showed information regarding the kind of study, approach, population, data collection techniques, and tools. As regards data collection, the semi-structured interview (used in 36 of the productions) stands out. While regarding data analysis procedures, 29 articles mentioned the adoption of content analysis, eight employed comparative analysis, and 14 referred to other types of analysis.

The articles that referred to the use of more than one data collection technology typically matched interview and observation $^{(7-11)}$ or interview and focal group ${ }^{(12-16)}$, and two articles associated interview, observation, documentary analysis, and focal group ${ }^{(17-18)}$. An interesting finding was that 31 articles mentioned the use of software to assist data handling and analysis, where the most widely used was the $\mathrm{NVi}^{-}$ vo $^{(7,9,12,15,19-27)}$, followed by Atlas ti ${ }^{(28-33)}, \operatorname{Maxqda}^{(10,34)}, \operatorname{SPSS}^{(9,31)}$, QSR 6 65-36), Excel $^{(37-38)}$ (two articles in each), PASW18 ${ }^{(39)}$, KWalitan 5.0 $0^{(40)}$ and Alceste ${ }^{(41)}$ (one article in each).

The 76 productions analyzed were published in 56 journals with international circulation, where the most frequent one was BMC Family Practice with seven articles, followed by the British Journal of General Practice and the Journal of General Internal Medicine (four articles in each). In this regard, an important datum is that five journals were part of the same system, BioMed Central (BMC), owned by Springer Science and Business Media, a portal of science, technology, and medicine that includes 276 open-access journals.

Data organized in the summary table - jointly with the recurrent reading of integral articles - were analyzed according to the referential adopted for the integrative review that allowed viewing the data, making comparisons, and identifying topic standards ${ }^{(5)}$ leading to the classification of these articles into eight thematic categories. The discussion of categories is grounded in the content of the articles selected, which structures each category.

\section{DISCUSSION}

Today daily drug utilization is a reality for the elderly who must deal with it as it is an important means to manage their health. This reality is typically found by health professionals in their everyday experience. In the face of this and in order to serve this population, professionals should be updated and rely on the literature as an important source to respond to the questions posed to them in their professional practice. This review allowed the identification of the different views of researchers about the object of study discussed herein, namely drug utilization in the elderly. In this way, going beyond the methodological aspects of article reviews, this paper also tried to identify the scope of the study objects to further classify them into thematic categories that depict the state of the art in this matter, pooling findings according to their affinities.

The studies showed, as broadly discussed topics, the emerging issues around drug utilization security, the adoption of integrative and complementary practices, the aid of technologies to manage drug-based treatment, the use of psychotropics, adherence to treatment, attitude and selfcare in those with chronic diseases, and the role played by the support network in the meantime. For publications on topics known in the literature, the researchers emphasize the advances and constraining factors of these studies, which seem to be a requirement on the part of international journals these days. The content of these studies is presented below, in eight categories defined through reading and detailed analysis.

\section{Drug UTILIZATION SECURITY: AvoIDING MISTAKES AND POTENTIALLY INAPPROPRIATE DRUGS (PID)}

Aging causes changes in the absorption, distribution, bio-transformation, and elimination of drugs. The elderly tend to have reduced levels of serum albumin, which renders them more vulnerable to the acute effects of polypharmacy when several drugs that rely on protein transportation are prescribed together. For example, the use of warfarin and the risk of hemorrhage demands care, as do the benzodiazepines, because the elderly are more sensitive to drugs that act on the Central Nervous System (CNS) ${ }^{(42)}$.

The use of Acetylsalicylic Acid (ASA), for example, is very common to prevent cardiovascular diseases; however, its use involves the risk of bleeding and gastric symptoms such 
as pain, reflux, and heartburn ${ }^{(43)}$. The intake of nonsteroidal anti-inflammatory drugs (NSAIDs) can also cause similar discomforts. A study done with the elderly in Australia using NSAIDs to treat osteoarthritis showed that they were aware of the potential damage caused by these drugs which, many times, were referred to "poison" or addicting products. These people poorly understood the adverse effects and controlled these by limiting the frequency and dose of anti-inflammatory drugs. Many of these patients assigned to the physician the responsibility for evaluating any risk related to the use of NSAIDs, as they trusted in the physician's knowledge to make decisions about the treatment ${ }^{(44)}$.

Regarding control and prevention of cardiovascular diseases, some professionals consider the use of drugs according to the patient's race. Some American physicians state that there are different effects of the Angiotensin-Converting Enzyme inhibitors (ACE inhibitors) according to the race and therefore these are not the best option to treat high blood pressure in black people. However, other respondents recognized the potential renoprotective effect provided by these drugs and showed concern that black patients might not be taking advantage of such positive effects ${ }^{(45)}$.

Three articles highlighted the common errors that affect security regarding drug utilization in the elderly, including forgetting the dosing time ${ }^{(46)}$ and the professional-patient communication gap ${ }^{(23,47)}$. In some cases patients felt as if they were not taken seriously during medical visits, and professionals ended up not clarifying their doubts about the drugs' adverse effects. In addition, there are misunderstandings regarding information written on medical prescriptions in two main ways: unclear instructions that do not properly explain the time span between doses, and very complex instructions written in language that is hard for participants to understand ${ }^{(23,47)}$.

Polypharmacy is a phenomenon that may affect safe drug utilization, and could be defined as the use of three or more drugs or of a dosage above the recommended amount. Many polypharmacy cases are due to lack of regular review of the therapeutic regime by health professionals, and also to the strict compliance with guidelines that many times leads to prescribing a large number of drugs ${ }^{(48)}$. Polypharmacy predisposes the elderly to the risk of being prescribed with potentially inappropriate drugs (PID), that is, those where the actual or potential damages of the therapy exceed the benefits. Among the factors that can minimize PID are: experience; technical skill; dialogue with patients; incentive to review treatments; and an attitude favorable to non-prescription. The identification, suspension, or reduction of inappropriate drug dosages should be a priority for the patients' safety ${ }^{(49)}$.

For polypharmacy an option to simplify treatment, reduce errors, and save time is the adoption of polypills, which are pills with a combination of the drugs being used by the patient. However, there are some concerns about the safety and efficacy, as well as regarding the rigidity of the dose, of each polypill component ${ }^{(21)}$.

A study performed in Rio Grande do Sul described initiatives by a program of home pharmacy care that proved to be efficacious in solving the problems reported by patients. It identified 13 drug-related negative effects that were solved in less than one month; moreover, all problems related to drugs storage were solved as well. In these programs, actions are performed by interdisciplinary teams, with the aim of evaluating whether complaints result from illness or are just adverse reactions. In the hypothesis of adverse reactions, the prescription is changed and the patient is monitored to observe outcomes ${ }^{(50)}$.

Another problem that affects safe drug utilization is the dependence on or abusive use of benzodiazepines (BZDs). Many chronic patients are aged individuals who began to trust and develop a psychological dependence on BZDs and their calming properties, to the point of denying or minimizing the report of side effects so as to avoid having to cease using the drug ${ }^{(12,24)}$.

Part of the elderly's health problems can be treated by changing their lifestyles, as many times pharmacologic interventions do not have sound justification. Although primary care is aimed at prevention, many times this prevention is through drugs. Avoiding inappropriate prescriptions to prevent complications related to polypharmacy can improve the elderly's quality of life $\mathrm{e}^{(51)}$.

\section{THE USE OF TOOLS/TECHNOLOGIES TO MANAGE DRUG THERAPY}

Recently Information and Communications Technologies (ICT) have been used, among other applications, to reduce discrepancies between the drugs listed in patients' medical charts and those that patients affirm they use. This is a way of reducing discrepancies and helping to avoid adverse events $^{(7)}$.

Researchers have developed and applied tools that can be useful and patient-friendly for both patients and professionals. Several tools were developed to identify inappropriate prescriptions and avoid damage to people's health, particularly the elderly, who are more vulnerable to adverse outcomes. The STOPP \& START (Screening Tool of Older Person's Prescriptions and Screening Tool to Alert Doctors to Right Treatment), created in 2008 and popular in Europe, is an important tool. It is made up of two criteria rolls that approach the excesses or improper prescriptions of potentially inappropriate drugs (PID) and also allow for detecting the risk of under-prescription ${ }^{(17,19)}$.

Following are some of the initiatives by professionals when they identify cases of PID: suspend the drug; reduce the dose; add another drug; or change to an alternative treatment $^{(19)}$.

An important tool that increases drug utilization safety is the Med-STEP - an online system to control blood pressure and allow for self-titration in patients suffering from hypertension and diabetes who are served by a primary health care service. The participants in the study that developed this tool reduced blood pressure values during monitoring by the research team, who assessed this outcome as positive ${ }^{(15)}$.

Warnings about prescription are another way of improving drug utilization security, and can be adopted in services 
using electronic medical reports. Researchers from Indianapolis in the USA have developed a system that sends warnings as pop-ups when physicians fill in a patient's prescriptions. By the time of publication the tool had two standardized messages: a warning when a patient was over 65 years old, and another when a patient had a creatinine clearance lower than 50 . The physicians participating in the research considered the system interface inadequate, and suggested that the system automatically relate changes on lab exams to the medications prescribed ${ }^{(10)}$.

Moreover, patient-focused warnings have been developed, such as sending messages via mobile to patients with Chronic Obstructive Pulmonary Disease (COPD) informing them of the drug dose time and providing information on weather conditions that contribute to reducing or increasing patients' exposure to risks ${ }^{(52)}$. Another proposal identified in this review to simplify therapy regime monitoring by patients was the use of a multidrug punch card. This strategy allows good visualization of drugs and helps to reminding about the doses, in addition to being a hygienic way of storing pills ${ }^{(34)}$.

Similarly, there are simple measures that can help the elderly to manage drug utilization in their everyday lives, such as: always placing drug flasks in the same order of use; using phone alarms to warn about the dose time; and always keep some pills on the person or in a purse to prevent missing a dose $\mathrm{e}^{(31)}$. The use of adhesive labels on the flasks showing symbols that recall the time or function of the drug, for example, is a useful mechanism for older patients, mainly those with problems reading and/or understanding the instructions displayed on the labels ${ }^{(53)}$.

Regardless of the strategy used, we should bear in mind that these technologies should be built based not only on the opinions of experts and/or the literature, but should consider the opinions of those who will use these tools to manage their drug therapy every day ${ }^{(30)}$.

\section{THE USE OF PSYCHOTROPICS}

Today, anxiety and depression are disorders commonly found among primary health care patients, demanding qualified human resources to deal with these cases and, among other factors, help adherence to the drug therapy. Despite the several forms of treating people with mental disorders that can also help in treating depression, this last remains focused on drug therapy ${ }^{(39)}$. A study performed in three primary care services in England showed that antidepressant drug therapy usually starts when patients have exhausted all other possibilities or have hit bottom. In fact, older people and Asian women showed more willingness toward following the prescription of antidepressants, stating that, in their eagerness to relieve symptoms, they would strictly do whatever their physicians prescribed ${ }^{(54)}$.

For those using antidepressants in the US, some strategies proved to be useful for elderly people to remember to take their medications, for example: placing the medication on the headboard when the drug is to be taken before bedtime, and the use trays organized by weekday to prevent forgetting a dose $\mathrm{e}^{(55)}$.
Nonetheless, the stigma related to the use of antidepressants remains, as some believe they are illegal and nonnatural substances that cause addiction when used for long periods of time. This fear is an important barrier against adherence to therapy, which could be worsened in some older people who are pessimistic regarding the chances of healing as they get older ${ }^{(35,56)}$.

\section{AdHerenCE TO DRUG THERAPY}

Adherence to drug therapy should not be considered meaningless, as it results from the subjective experiences of people living with given diagnoses and treatments. The fear of treatment and lack of information worsened by the reluctance to clarify doubts with physicians are factors that hinder adherence to therapy ${ }^{(57)}$. The lack of symptoms, blood pressure control of hypertensive individuals, and distance between home and the health service were also mentioned as reasons for abandoning treatment ${ }^{(58)}$.

Persisting in a therapy involves personal motivation and self-care capacity, in addition to skills to evaluate the drug utilization risks and search for information ${ }^{(36)}$. In the household context, treatment is influenced by the patient's beliefs, living habits, and the drug characteristics ${ }^{(59)}$.

Patients usually feel encouraged when professionals and the family provide support; however, the relation between this support and adhesion has not been proved. Having a routine that includes taking the drug or drugs is a factor that seems to help adherence ${ }^{(36)}$. However, in some cases family can be a barrier to drug therapy. An example was found in a study performed in Malaysia with insulin-dependent diabetes patients, where some family members disagreed with the use of insulin because it is perceived as a drug for the elderly that causes sexual dysfunction or which is prohibited to Muslims, just to mention some misinterpretations ${ }^{(60)}$.

In addition to insulin, another stigma was observed: the use of opioids. Here, barriers took the form of both resistance by the family because of the fear of addiction and the costs of purchase, and by professionals, as these stated that pain evaluation is subjective and does not necessarily require the prescription of this class of drugs ${ }^{(22)}$.

Imagining that in some situations health professionals may raise barriers that hinder therapy adherence is something quite intriguing and has been discussed in some of the articles identified. A relationship of trust between professionals and patients; the use of legible handwriting on prescription forms; and leaving room to clarify doubts regarding the therapy were referred to as important elements to be adopted to deal with the stress of multiple comorbidities and to adhere to treatment ${ }^{(11)}$.

In some realities there is a true pilgrimage in the search for a drug and, when it is not available, patients follow one of two paths: most prefer purchasing it, even if it represents extra expenses to the family; others resort to judicial means to get the medications included in the official public lists ${ }^{(11)}$. For this review, only one article approached the health judicialization phenomenon; it referred to a survey developed in the south region of Brazil and showed the difficulties to purchase some drugs ${ }^{(11)}$. It is known that judicial means 
have been sought in other South American countries as a way of having access to medications, but the scope of this phenomenon - national or global - cannot be ascertained, as we have found only one study, a Brazilian one, in a corpus that comprises productions from 16 different countries.

Despite the many difficulties posed by the health service, professionals, patients, and their families, we should attempt to overcome the barriers, seeking strategies to solve or minimize the problems disclosed by the abovementioned studies.

In addition to the primary health care team professionals, the pharmacist should also be engaged in supervising the community members' health in order to monitor patients and provide information. Health services might also employ simple but important strategies such as distribution of organizer trays to facilitate patients' organizing their medications according to doses and time, which could be a useful tool for adherence, mainly for the elderly with multiple medications ${ }^{(14)}$.

\section{THE USE OF INTEGRATIVE AND COMPLEMENTARY PRACTICES}

Altogether, we have identified five articles that approached the use of Integrative and Complementary Practices (ICP) or Alternative and Complementary Medicine (ACM), using the terms used by the Brazilian Ministry of Health and the WHO, respectively.

Some authors emphasize that, as these are natural treatments, their use poses less risk to health in comparison with industrialized drugs, but these authors also state that these treatments are not free from potential adverse reactions ${ }^{(26)}$. A study from the USA showed that the most popular ACM types among participants were herbs (powders, teas, or extracts), nutritional supplements and foods rich in soy, meditation, acupuncture, massage, and Reiki. Participants were menopausal women who explained that ACM was safer and less harmful than hormone therapy, claiming that women in previous generations were treated only with natural things ${ }^{(26)}$.

For a group of older men in the mid-west region of Brazil, plants were viewed as different from health care unit drugs, as herbs took longer to be effective and could only help the treatment prescribed by the physician. Herbs were considered to be a supplementary resource and only took a leading role in the treatment of less serious morbidities, such as tea for the flu. Respondents referred to 34 medicinal plants, mainly guaco and lemon balm, which would serve to treat the flu and as calming, respectively. The meanings assigned to these herbs were learned from their ancestors and popular knowledge, reinforcing the idea that the elderly are the guardians of herbal medicine ${ }^{(61)}$.

In the Brazilian reality, researchers who investigated the experience of primary and secondary healthcare patients regarding the use of acupuncture found the following as main reasons to resort to this treatment: failure of a solution to their problems using conventional treatments. They complained about the bad effects of drugs used for long periods of time and saw acupuncture as an alternative, or they were referred to acupuncture by a physician or wanted acupunc- ture due to complaints of pain. According to the survey, the primary healthcare environment seemed to favor the use of acupuncture and other modalities of Chinese Traditional Medicine $(\mathrm{CTM})^{(62)}$.

This finding is reinforced by the results of a study(37) where professionals advocated the importance of using alternative and complementary therapies in primary health care, based on the following reasons: reduced financial cost to the SUS; fewer side effects in comparison with other practices; and as an alternative to the abusive use of anxiolytics and excessive medicalization found in health services. Some professionals were concerned and avoided recommending herbal therapy due to the lack of technical knowledge due to the short duration of medical visits, fearing that the patient would stop the drug therapy and in this way worsen their health condition.

\section{Attitudes OF THE SUBJECT REGARDING DRUGS}

Considering that today there is a tendency towards increasing numbers of older people with chronic diseases, there is also a strong presence of continuous use of medications in this population.

Some patients believe that options diminish as the disease advances, prefer physicians to make decisions about the treatment, and do not seek for further information. Their attitudes may represent the concern or lack of concern regarding drug therapy in three groups: those who do not know what drugs are for and/or their side effects; those who knew the names and main side effects and relied on physicians to provide further information; and those who understood their diagnosis and were committed to always discovering more ${ }^{(63)}$.

Among older men in Mato Grasso do Sul, the most commonly prescribed drugs were: captopril; hydrochlorothiazide; enalapril; losartan; digoxin; simvastatin; carvedilol; atenolol; and chlorthalidone. Here was observed the prevalence of everyday and permanent drugs to treat high blood pressure and other cardiovascular diseases and to control hypercholesterolemia ${ }^{(64)}$.

Participants in another study did not consider high cholesterol to be a disease, as there were no perceived symptoms, and said to treat it only with drugs because there is a number that shows changes in laboratory exams ${ }^{(13)}$. In these cases, the use of drugs is a practice incorporated into the everyday life of these aged people and this incorporation follows the Western medical rationality model. The fact that life is strongly dependent on medications can lead to restrictions in social and personal activities, notably for those taking several drugs a day, regardless of whether for preventive reasons, for a specific treatment, or a symptomatic treatment ${ }^{(13,64-65)}$.

A survey carried out in England with people suffering from chronic pain aged 62 on average showed that symptomatic drugs are perceived in three ways: either as a miracle because they reduce pain; as drugs to be used as a last resort; or as a drug that provides temporary relief. People showed a willingness to do whatever it took to improve; however, first they tried to understand the cause of the pain in order 
to treat it in a more specific way rather than exclusive with symptomatic drugg ${ }^{(20)}$.

Women were the target of an important survey about osteoporosis treatment where the most influent factors regarding their view on the use of drugs were related to the drug's effectiveness and safety, perceptions about the need for drug, and patients' interactions with physicians. It seems that older women do not always express their concerns and doubts about treatment, reinforcing the importance of the professional's guidance regarding their diagnosis, treatment, and implications ${ }^{(66)}$.

An issue regarding health care to the elderly in Brazil regards the supply and distribution of medications in primary health care, because many times this is the only resource available to treat multiple morbidities. Among the medications distributed we should mention generic drugs that, in some situations, are considered by older people to be weak, fake, or lower-quality drugs in comparison with the branded medicine On the other hand, there are positive feelings of credibility and reliability, and generic drugs are praised for their more affordable prices ${ }^{(41)}$.

\section{Self-Care In PeOPle With Non-COMmunicable Chronic Diseases (NCD)}

People suffering from chronic diseases may report a strong dependence on drugs, affecting their well-being and involving costs and adverse effects. A recent study showed that people with high blood pressure, diabetes, and hypercholesterolemia took 4.8 drugs a day on average. Such consumption is fostered not only by individual health needs, but also by the strong influence of pharmaceutical industry marketing ${ }^{(9)}$.

Those using polypharmacy have more chances of facing economic problems and thus their capacity to actively selfmanage their chronic condition and reduce risk behaviors is damaged. Even those eligible for government assistance with treatment also face economic problems, as benefits are typically insufficient to cope with health expenses and adopt healthy habits ${ }^{(67)}$.

Regarding care for chronic conditions, the elderly seem to rank medicines, attaching priority to those for more serious diseases that demand more care in usage, to the detriment of those they consider to relieve lesser symptoms. This and other behaviors of hypertensive older people are strategies they find to deal with multiple morbidities and drugs in their everyday lives ${ }^{(68)}$.

Treating one or more chronic conditions implies overload on older people's lives. For people with cardiovascular diseases, for example, this load includes the need to understand treatment; self-care and interaction with family members, professionals, and caregivers to organize care; medical visits; polypharmacy; and adoption of changes in lifestyle ${ }^{(69)}$.

In some situations those elderly committed to dietary habits and exercise can present lower levels of adherence to the use of drugs. Low adherence to drug therapy for chronic diseases is probably due to the dual nature of the drugs they emphasize: these drugs ameliorate symptoms and improve life quality, but also lead to adverse reactions and the emergence of new symptoms ${ }^{(70)}$.
Self-monitoring is an important strategy that may be adopted by those who manage self-care and try to control chronic diseases such as high blood pressure. This review identified three articles that recommended this practice, as it motivates individuals to become more involved in their own care and have a better understanding of the disease. Measuring blood pressure at home improved the relationship between patients and professionals, as they started discussing the values observed during medical visits ${ }^{(16,71-72)}$.

Generally speaking, when people are diagnosed with a chronic disease, they develop new behaviors to manage their health, including taking drugs correctly and adopting healthy habits to take care of their health ${ }^{(73)}$. However, sometimes accepting living with a permanent condition is not as simple as the literature describes. The individual's engagement in self-care demands the support of family members and health professionals working in an interdisciplinary way.

The literature confirms a common fact in professional practice: older people with multiple morbidities take multiple drugs. One of the reasons for this polypharmacy is the duplication of prescriptions, in the case of care that is not coordinated among the professionals taking care of the older person, for example. In this sense, studies of the American elderly treating chronic pain suggested that, if professionals communicated with one another and observed the notes of other professionals in the medical records, many double prescriptions would be avoided and many problems could be solved by seeking non-pharmacological strategies ${ }^{(74)}$.

\section{THE ROLE PLAYED BY THE SUPPORTING NETWORK IN DRUG THERAPY}

Researchers from Maringá, Paraná, identified at least three facets of the supporting network to hypertensive individuals: the formal network; the family network; and community social networks. The formal supporting network is represented by health professionals and plays an important role of support to hypertensive people in case they feel any symptom or to clarify doubts. However, among all professions only the physician was mentioned as the professional patients sought out to clarify doubts, and participants said that is so because physicians are responsible for the diagnosis and prescription of drugs ${ }^{(75)}$.

At least seven other articles emphasized the sovereign role played by physicians in drug therapy ${ }^{(27-28,33,76-79)}$. This can be reinforced by the fact that many people follow drug therapy without arguing or challenging the prescriptions because they completely trust their physicians ${ }^{(25)}$.

In some realities there persists a relationship of dominance between physicians and the elderly, characterized by little dialogue, scientific language that is hard for patients to understand, illegible handwriting, etc. All these factors lead to detachment and vertical interactions. However, some patients reported they feel respected and appraised, favoring communication, improving their understanding about their disease, and reducing the risks related to the utilization of drugs ${ }^{(80)}$. Communication between health professionals and patients seems to be a topic to be further studied in 
health care, as another study ${ }^{(81)}$ referred to it as inefficient competence.

Insufficient guidance on hospital discharge, for example, can lead to misinterpretations and misuse of drugs when the patient returns home after hospitalization. People have different needs of information about drugs but, in general, say the ideal would be to also receive discharge guidance in writing ${ }^{(40)}$.

In addition to the need for guidance, other common issues found regarding drug prescription by physicians are: non-adherence; fear about adverse effects; drug interactions and cost of treatment; and lack of understanding by patients regarding their therapy. An interesting aspect was that patients appraised a medication therapy management (MTM) service coordinated by pharmacists, but said that physicians would be better fit to that role because they know their patients better and have deeper clinical knowledge. Physicians questioned how they would be compensated for the time spent in this activity when coordinating care delivered to their patients ${ }^{(28)}$.

The role and attitudes of other health team professionals regarding the use of medications is also an object of study in many countries. The pharmacist, for example, is referred to in some studies as someone skilled in providing guidance on the rational use of medications, warning about side effects, and capable of mediating the physician/patient relationship ${ }^{(29,38)}$. On the other hand, other authors ${ }^{(18)}$ found that the natural attitude of pharmaceutics negatively affects care as they usually disregard the patient's individual issues. These authors suggest that pharmacists should recognize, ask, and reflect more in their everyday practice, as patients want to be heard and have their experiences analyzed in an individual way.

Nurses were also targeted by surveys that evaluated as positive their engagement with medical visits and medication prescriptions; respondents said that nursing visits are unhurried, valuing care continuity, and providing clear and science-based guidance ${ }^{(32)}$

Studies have also emphasized the important role played by family regarding home health care to the elderly or patients with chronic diseases, because family members must be aware of effects, ways of using medications, and other aspects of the patient's medication therapy ${ }^{(25,82)}$. Among the strategies managed by family members we can mention: reducing medication therapy costs and the adoption of natural practices, religiosity, and affectivity as care elements ${ }^{(8)}$.

\section{CONCLUSION}

The results achieved in this review showed that drug utilization is a broad topic that can be studied from different perspectives and with different methods. Here we decided to study this topic in the context of primary health care and its effects on care to the elderly, because many times medication therapy occupies a central axis around which different health aspects of aging people circulate.

As we get older, our organisms undergo changes that may modify the action of some drugs and either increase or reduce their effects. As such, to improve safety in drug utilization, the studies reviewed provide some recommendations to health professionals that can be summarized as follows: review the list of home drugs and medications of each older person, considering the data in medical records and the information provided by them during medical visits; consider the peculiarities of the aging process when recommending a treatment; improve communication and make therapeutic relations more horizontal; instruct elderly patients about treatment and encourage the search for information; search for and adopt into care the use of devices/technologies that facilitate the identification of drugs and help the elderly to remember time and doses.

The adoption of these practices can bring about good results in health care as, for example, when we improve professional/patient communication we can make room for the exchange of information, clarify doubts about treatment, identify complaints about adverse effects and, in this way, build a relationship of mutual trust and strengthen links with the population. When they are better informed about the treatment's purposes and the risks of following it or not, people are better skilled for self-care, adhere more to treatments, and are less exposed to complications resulting from the overuse or underuse of medication. Thus, numerous cases of iatrogenesis and hospitalization would be avoided in the elderly, reducing costs for the health system and their families, so that people's time of life could be devoted not only to treating diseases, but to living with quality.

\section{RESUMO}

Objetivo: Identificar o conhecimento produzido sobre o uso de medicamentos por idosos no contexto da atenção primária à saúde, entre os anos de 2006 e 2014. Método: Revisão integrativa realizada nas bases de dados PubMed, LILACS, BDENF e SCOPUS, incluindo artigos de pesquisa qualitativa em português, inglês e espanhol. Foram excluídos aqueles cuja descrição metodológica trazia informações insuficientes. Resultados: As buscas levaram a 633 artigos que, após a aplicação dos critérios de inclusão e exclusão, formou-se um corpus de 76 produções, em sua maioria publicadas em língua inglesa e produzida nos EUA, Inglaterra e Brasil. Os resultados foram distribuídos em oito categorias temáticas e apontaram uma tendência do que tem sido o uso de medicamentos em idosos, destacando-se o uso de psicotrópicos, a polifarmácia, a prevenção de eventos adversos e adoção de tecnologias que facilitem o manejo dos medicamentos por parte do idoso. Os estudos apontam os riscos aos quais os idosos estão expostos devido às mudanças na metabolização e ao uso concomitante de vários medicamentos. Conclusão: Há uma forte preocupação com a melhora da comunicação entre profissionais e idosos no sentido de troca de informações sobre a terapia a fim de evitar maiores complicações à saúde dessa população.

\section{DESCRITORES}

Uso de Medicamentos; Idoso; Atenção Primária à Saúde; Enfermagem Geriátrica; Revisão. 
RESUMEN

Objetivo: Identificar el conocimiento producido sobre el uso de fármacos por ancianos en el marco de la atención primaria de salud, entre los años 2006 y 2014. Método: Revisión integradora llevada a cabo en las bases de datos PubMed, LILACS, BDENF y SCOPUS, incluyendo artículos de investigación cualitativa en portugués, inglés y español. Fueron excluidos aquellos cuya descripción metodológica traía informaciones insuficientes. Resultados: Las búsquedas llevaron a 633 artículos que, luego de la aplicación de los criterios de inclusión y exclusión, conformaron un corpus de 76 producciones, en su mayoría publicadas en lengua inglesa y producida en los EE.UU. y Brasil. Los resultados fueron distribuidos en ocho categorías temáticas y señalaron una tendencia de lo que está siendo el uso de fármacos en ancianos, destacándose el uso de psicotrópicos, la polifarmacia, la prevención de eventos adversos y la adopción de tecnologías que faciliten el manejo de los fármacos por parte del anciano. Los estudios señalan los riesgos a los que los ancianos están expuestos debido a los cambios en la metabolización y el uso concomitante de varios fármacos. Conclusión: Existe una fuerte preocupación por la mejora de la comunicación entre profesionales y ancianos con respecto al intercambio de informaciones acerca de la terapia a fin de evitar complicaciones a la salud de dicha población.

\section{DESCRIPTORES}

Utilización de Medicamentos; Anciano; Atención Primaria de Salud; Enfermería Geriátrica; Revisión.

\section{REFERENCES}

1. Organización Panamericana de la Salud; Organización Mundial de la Salud. Módulo 6. Evaluación farmacológica del adulto mayor. Nueva York: OMS; 2002.

2. Secoli SR. Polifarmácia: interações e reações adversas no uso de medicamentos por idosos. Rev Bras Enferm. 2010;63(1):136-40.

3. Farias RG, Santos SMA. Influência dos determinantes do envelhecimento ativo entre idosos mais idosos. Texto Contexto Enferm. 2012;21(1):167-76.

4. Nascimento AB, Corrêa EC, Grossi SAA, Lottenberg SA. The relationship between polipharmacy, chronic complications and depression in individuals with Type 2 Diabetes Mellitus. Rev Esc Enferm USP. 2010;44(1):39-45.

5. Whittemore R, Knafl K. The integrative review: updated methodology. J Adv Nurs. 2005;52(5):546-33.

6. World Health Organization. The safety of medicines in public health programmes: pharmacovigilance an essential tool [Internet]. Geneva:WHO; 2006. Available from: http://www.who.int/medicines/areas/quality_safety/safety_efficacy/Pharmacovigilance_B.pdf

7. Heyworth L, Clark J, Marcello TB, Paquin AM, Stewart M, Archambeault C, et al. Aligning medication reconciliation and secure messaging: qualitative study of primary care providers' perspectives. J Med Internet Res. 2013;15(12):e264.

8. Carreira L, Rodrigues RAP. Estratégias da família utilizadas no cuidado ao idoso com condição crônica. Ciênc Cuid Saúde. 2006;5 Supl:119-26.

9. Hunt LM. The changing face of chronic illness management in primary care: a qualita- tive study of underlying influences and unintended outcomes. Ann Fam Med. 2012;10(5):452-60.

10. Russ AL. Prescribers' interactions with medication alerts at the point of prescribing: a multi-method, in situ investigation of the human: computer interaction. Int J Med Inform. 2012;81(4):232-43.

11. Guerin GD, Rossoni E, Bueno D. Itinerários terapêuticos de usuários de medicamentos de uma unidade de Estratégia de Saúde da Família. Ciênc Saúde Coletiva. 2012;17(11):3003-10.

12. Payne M, Gething M, Moore AA, Reid MC. Primary care providers' perspectives on psychoactive medication disorders in older adults. Am J Geriatr Pharmacother. 2011;9(3):164-72.

13. Kirkegaard P, Edwards A, Risør MB, Thomsen JL. Risk of cardiovascular disease ? A qualitative study of risk interpretation among patients with high cholesterol. BMC Fam Pract. 2013;14:137.

14. DuPasquier S, Aslani P. Concordance-based adherence support service delivery: consumer perspectives. Pharma World Sci. 2008;30(1):846-53.

15. Grant RW, Pandiscio JC, Pajolek H, Woulfe A, Pelletier A, Kvedar J, et al. Implementation of a web-based tool for patient medication self-management: the Medication Self-titration Evaluation Programme ( Med-STEP) for blood pressure control. Inform Prim Care. 2012;20(1):57-67.

16. Abdullah A, Othman S. The influence of self-owned home blood pressure monitoring ( HBPM ) on primary care patients with hypertension : a qualitative study. BMC Fam Pract [Internet]. 2011 [cited 2015 May 16];12:143. Available from: http://www.ncbi.nlm.nih.gov/pmc/articles/ PMC3271963/

17. Dalleur O, Feron J, Spinewine A. Views of general practitioners on the use of STOPP \& START in primary care: a qualitative study. Acta Clin Belg. 2014;69(4):251-61.

18. Oliveira DR, Shoemaker SJ. Achieving patient centeredness in pharmacy practice: openness and the pharmacist's natural attitude. J Am Pharm Assoc. 2006;46(1):56-66.

19. Clyne B, Bradley MC, Hughes CM, Clear D, Mcdonnell R, Williams D, et al. Addressing potentially inappropriate prescribing in older patients : development and pilot study of an intervention in primary care (the OPTI-SCRIPT study). BMC Health Serv Res [Internet]. 2013 [cited 2015 May 16];13:307. Available from: http://www.ncbi.nlm.nih.gov/pmc/articles/PMC3751793/

20. Dima A, Lewith GT, Little P, Moss-Morris R, Foster NE, Bishop FL. Identifying patients' beliefs about treatments for chronic low back pain in primary care: a focus group study. Br J Gen Pract. 2013;63(612):e490-8.

21. Bryant L, Martini N, Chan J, Chang L, Marmoush A, Robinson B, et al. Could the polypill improve adherence? The patient perspective. J Prim Heal Care. 2013;5(1):28-36.

22. Spitz A, Moore AA, Papaleontiou M, Granieri E, Turner BJ, Reid MC. Primary care providers ' perspective on prescribing opioids to older adults with chronic non-cancer pain : qualitative study. BMC Geriatr [Internet]. 2011 [cited 2015 May 16];11:35-44. Available from: http:// www.ncbi.nlm.nih.gov/pmc/articles/PMC3212901/ 
23. Wolf MS, Davis TC, Shrank W, Rapp DN, Bass PF, Connor UM, et al. To err is human: patient misinterpretations of prescription drug label instructions. Patient Educ Couns. 2007;67(3):293-300.

24. Cook JM, Biyanova T, Masci C, Coyne JC. Older patient perspectives on long-term anxiolytic benzodiazepine use and discontinuation : a qualitative study. J Gen Intern Med. 2007;22(8):1094-100.

25. While C, Duane F, Beanland C, Koch S. Medication management : the perspectives of people with dementia and family carers. Dementia. 2012;12(6):734-50.

26. Hill-Sakurai LE, Muller J, Thom DH. Complementary and alternative medicine for menopause : a qualitative analysis of women's decision making. J Gen Intern Med. 2008;23(5):619-22.

27. Franz CE, Barker JC, Kravitz RL, Flores Y, Krishnan S, Hinton L. Nonmedical influences on the use of cholinesterase inhibitors in dementia care. Alzheimer Dis Assoc Disord. 2007;21(3):241-8.

28. Mcgrath SH, Snyder ME, Dueñas GG, Pringle JL, Smith RB, Mcgivney MS. Physician perceptions of pharmacist-provided medication therapy management: qualitative analysis. J Am Pharm Assoc. 2010;50(1):67-71.

29. Tarn DM, Paterniti DA, Wenger NS, Williams BR, Chewning BA. Older patient, physician and pharmacist perspectives about community pharmacists' roles. Int J Pharm Pract. 2012;20(5):285-93.

30. Lauffenburger JC, Vu MB, Burkhart JI, Weinberger M, Roth MT. Design of a medication management program for medicare beneficiaries: qualitative findings from patients and physicians. Am J Geriatr Pharmacother. 2012;10(2):129-38.

31. Finnell DS, Osborne FH, Gerard VK. Development of the patient-centered recovery resource system for veterans on long-term mental health medications. Arch Psychiatr Nurs. 2011;25(4):235-44.

32. Stenner KL, Courtenay M, Carey N. Consultations between nurse prescribers and patients with diabetes in primary care: a qualitative study of patient views. Int J Nurs Stud. 2011;48(1):37-46.

33. Tarn DM, Paterniti DA, Williams BR, Cipri CS, Wenger NS. Which providers should communicate which critical information about a new medication? Patient, pharmacist anda physician perspectives. J Am Geriatr Soc. 2009;57(3):462-9.

34. Boeni F, Hersberger KE, Arnet I. Multidrug punch cards in primary care: a mixed methods study on patients ' preferences and impact on adherence. Front Pharmacol. 2014;5:220.

35. Givens JL, Datto CJ, Ruckdeschel K, Knott K, Zubritsky C, Oslin DW, et al. Older patients' aversion to antidepressants. Gen Intern Med. 2006;21(2):146-51.

36. Borgsteede SD, Westerman MJ, Hugtenburg JG. Factors related to high and low levels of drug adherence according to patients with type 2 diabetes. Int J Clin Pharm. 2011; 33(5):779-87.

37. Fontenele RP, Maria D, Sousa P, Oliveira FDA. Fitoterapia na Atenção Básica: olhares dos gestores e profissionais da Estratégia Saúde da Família de Teresina (PI), Brasil. Ciênc Saúde Coletiva. 2013;18(8):2385-94.

38. Costa EM, Rocha A, Rabelo DM, Lima JG. Avaliação do papel do farmacêutico nas ações de promoção da saúde e prevenção de agravos na atenção primária. Rev Ciênc Farm Básica Apl. 2014;35(1):81-8.

39. Kitchen KA, Mckibbin CL, Wykes TL, Lee AA, Carrico CP, Mcconnell KA. Depression treatment among rural older adults: preferences and factors influencing future service use. Clin Gerontol [Internet]. 2013 [cited 2015 May 16];36(3). Available from: http://www.ncbi.nlm.nih. gov/pmc/articles/PMC3881270/

40. Borgsteede SD. Information needs about medication according to patients discharged from a general hospital. Patient Educ Couns. 2011;83(1):22-8.

41. Nóbrega SB, Costa SMG, Peixoto TR, Silva LM, Queiroga ASG, Silva AO. Sentidos atribuídos aos medicamentos genéricos por idosons. J Res Fundam Care Online [Internet]. 2011 [citado 2015 maio 22]; Supl.: 37-44. Disponível em: http://www.seer.unirio.br/index.php/ cuidadofundamental/article/view/1937/pdf_523

42. Baldoni ADO, Chequer FMD, Ferraz ERA, Oliveira DP, Pereira LRL, Dorta DJ. Elderly and drugs: risks and necessity of rational use. Braz J Pharm Sci. 2010;46(4):617-32.

43. Margolis MK. Upper gastrointestinal symptoms experienced by users of low-dose aspirin (Acetylsalicylic Acid) $75325 \mathrm{mgday}$ for primary and secondary coronary artery disease prevention: perspectives from patient focus groups. Patient. 2009;2(2):85-93.

44. Milder TY. Use of NSAIDs for osteoarthritis amongst older-aged primary care patients: engagement with information and perceptions of risk. Age Ageing. 2011;40(2):254-9.

45. Frank D, Gallagher TH, Sellers SL, Cooper LA, Price EG, Odunlami AO, et al. Primary care physicians ' attitudes regarding race-based therapies. J Gen Intern Med. 2010;5(2):384-9.

46. Buetow S, Mcom JH, Student RCM, Sullivan DO. Distinguishing objective from subjective assessments of the severity of medication-related safety events among people with Parkinson's disease: a qualitative study. J Clin Pharm Ther. 2012; 37(4):436-40.

47. Burgess C, Cowie L, Gulliford M. Patients' perceptions of error in long-term illness care: qualitative study. J Heal Serv Res Policy. 2012;17(3):181-7.

48. Anthierens S, Tansens A, Petrovic M, Christiaens T. Qualitative insights into general practitioners views on polypharmacy. BMC Fam Pract. 2010;11:65.

49. Anderson K, Stowasser D, Freeman C, Scott I. Prescriber barriers and enablers to minimising potentially inappropriate medications in adults : a systematic review and thematic synthesis. BMJ Open. 2014;4(12):e006544.

50. Cardoso CK, Malheiros RT, Torres OM, Pinto M, Silveira T. Home pharmaceutical care: case studies of users of the integrated practice program in public health. Rev Ciênc Farm Básica Apl. 2013;34(2):263-8.

51. García Orihuela M. La evidencia científica y la intervención farmacológica preventiva en geriatría scientific evidence and preventive pharmacological intervention in geriatrics. Rev Cuba Med Gen Integr. 2012;28(4):747-55.

52. Cooper R, O'Hara R. Patients' and staffs' experiences of an automated telephone weather forecasting service. J Health Serv Res Policy. 2010;15 Suppl 2:41-6. 
53. Cardarelli R, Mann C, Fulda KG, Balyakina E, Espinoza A, Lurie S. Improving accuracy of medication identification in an older population using a medication bottle color symbol label system. BMC Fam Pract [Internet]. 2011 [cited 2015 May 22];12:142. Available from: http:// www.ncbi.nlm.nih.gov/pmc/articles/PMC3282670/

54. Schofield P, Crosland A, Waheed W, Aseem S, Gask L, Wallace A, et al. Patients' views of antidepressants: from first experiences to becoming expert. Br J Gen Pract. 2011;61(585):142-8.

55. Fortney JC, Pyne JM, Edlund MJ, Stecker T, Mittal D, Robinson DE, et al. Reasons for antidepressant nonadherence among veterans treated in primary care clinics. J Clin Psychiatry. 2011;72(6):827-34.

56. Izquierdo A, Sarkisian C, Ryan G, Wells B, Miranda J. Older depressed Latinos' experiences with primary care visits for personal, emotional and/or mental health problems: a qualitative analysis. Ethn Dis. 2014;24(1):84-91.

57. Marx G, Witte N, Himmel W, Kuhnel S, Simmenroth-nayda A, Koschack J. Accepting the unacceptable: medication adherence and different types of action patterns among patients with high blood pressure. Patient Educ Couns. 2011;85:468-74.

58. Duarte MTC, Cyrino AP, Cerqueira ATAR, Nemes MIB, Iyda M. Reasons for medical follow-up dropout among patients with arterial hypertension: the patient's perspective. Ciên Saúde Coletiva. 2010;15(5):2603-10.

59. Escamilla Fresnadillo JA, Cañaster Niño O, Benito López S, Ruiz Gil E, Burrull Gimeno MB, Sáenz Moya N. Motivos de incumplimiento terapéutico en pacientes mayores polimedicados. Aten Primaria. 2008;40(2):81-5.

60. Lee YK, Lee PY, Ng CJ. A qualitative study on healthcare professionals' perceived barriers to insulin initiation in a multi-ethnic population. BMC Fam Pract. 2012;13: 28.

61. Lima SCS, Arruda GO, Renovato RD, Alvarenga MRM. Representations and uses of medicinal plants in elderly men. Rev Latino Am Enferm. 2012;20(4):778-86.

62. Silva EDC, Tesser CD. Experiência de pacientes com acupuntura no Sistema Único de Saúde em diferentes ambientes de cuidado e (des) medicalização social. Cad Saúde Pública. 2013;29(11):2186-96.

63. Field K, Ziebland S, Mcpherson A, Lehman R. "Can I come off the tablets now ?" A qualitative analysis of heart failure patients ' understanding of their medication. Fam Pract. 2006;23(6):624-30.

64. Arruda GO, Lima SCS, Renovato RD. The use of medications by elderly men with polypharmacy: representations and pratices. Rev Latino Am Enferm. 2013;21(6):1337-44.

65. Krska J, Morecroft CW, Poole H, Rowe PH. Issues potentially affecting quality of life arising from long-term medicines use: a qualitative study. Int J Clin Pharm. 2013;35(6):1161-9.

66. Mazor K, Velten S, Andrade S, Yood R. Older women's views about prescription osteoporosis medication: a cross-sectional, qualitative study. Drugs Aging. 2010;27(12):999-1008.

67. Jeon Y, Essue B, Jan S, Wells R, Whitworth JA. Economic hardship associated with managing chronic illness: a qualitative inquiry. BMC Health Serv Res. 2009;9:182.

68. Renovato RD, Bagnato MHS. Hypertensive elderly people in primary health care: discourses and identities. Rev Bras Geriatr Gerontol. 2012;15(3):423-31.

69. Gallacher K, May CR, Montori VM. Understanding patients' experiences of treatment burden in chronic heart failure using normalization process theory. Ann Fam Med. 2011;9(3):235-43.

70. Löffler C, Kaduszkiewicz H, Stolzenbach C, Streich W, Fuchs A, van den Bussche H, et al. Coping with multimorbidity in old age: a qualitative study. BMC Fam Pract. 2012;13:45.

71. Jones MI, Greenfield SM, Bray EP, Hobbs FDR, Holder R, Little P, et al. Patient self-monitoring of blood pressure and self-titration of medication in primary care: the TASMINH2 trial qualitative study of health professionals' experiences. Br J Gen Pract. 2013;63(611):e378-85.

72. Jones MI, Greenfield SM, Bray EP, Baral-grant S, Hobbs FDR, Holder R, et al. Patients' experiences of self-monitoring blood pressure and self-titration of medication: the TASMINH2 trial qualitative study. Br J Gen Pract. 2012;62(595):e135-42.

73. Audulv $\AA$. The over time development of chronic illness self-management patterns : a longitudinal qualitative study. BMC Public Health. $2013 ; 13: 452$.

74. Lyons KJ, Salsbury SA, Hondras MA, Jones ME, Andresen AA, Goertz CM. Perspectives of older adults on co-management of low back pain by doctors of chiropractic and family medicine physicians: a focus group study. BMC Complement Altern Med. 2013;13:225.

75. Faquinello P, Marcon SS. A rede social como estratégia de apoio à saúde do hipertenso. Rev Bras Enferm. 2012;64(5):849-56.

76. Fried TR, Tinetti ME, lannone L. Primary care clinicians' experiences with treatment decisionmaking for older persons with multiple conditions. Arch Intern Med. 2011;171(1):75-80.

77. Tarn DM, Paterniti DA, Kravitz RL, Fein S, Wenger NS. How do physicians conduct medication reviews? J Gen Intern Med. 2009 ;24(12):1296-302.

78. Howes F, Hansen E, Williams D, Nelson M. Barriers to diagnosing and managing hypertension: a qualitative study in Australian general practice. Aust Fam Physician. 2010;39(7):511-6.

79. Tan NC, Tay IH, Ngoh A, Tan M. Factors influencing family physicians' drug prescribing behaviour in asthma management in primary care. Singapore Med J. 2009; 50(3):312-9.

80. Lyra Júnior DP, Marques TC, Miasso Al, Cassiani SHB. Compreendendo os significados das interações entre profissionais de saúde e idosos usuários de medicamentos. Rev Eletr Enf [Internet]. 2008 [citado 2015 maio 22];10(3):591-9. Disponível em: https://www.fen.ufg. br/fen_revista/v10/n3/pdf/v10n3a05.pdf

81. Bokhour BG, Berlowitz DR, Long JA, Kressin NR. How do providers assess antihypertensive medication adherence in medical. J Gen Intern Med. 2006;21(6):577-83.

82. Zanetti ML, Biagg MV, Santos MA, Péres DS, Teixeira CRS. O cuidado à pessoa diabética e as repercussões na família. Rev Bras Enferm. 2008;61(2):186-92. 